\title{
PENENTUAN HARGA POKOK PRODUKSI ES CILINDER DAN ES SERUT PADA ES ABADI SORONG
}

\author{
Menik Wijayanti, SE, M.Sc, \\ Akuntansi Keuangan Publik \\ Program Studi Sarjana Terapan Akuntansi Keuangan Publik \\ Politeknik Katolik Saint Paul Sorong \\ Email: menik wijayanti29@yahoo.co.id
}

\begin{abstract}
ABSTRAK
Es Abadi Sorong merupakan perusahaan perseorangan yang bergerak dalam bidang manufaktur yang memproduksi es cilinder dan es serut dalam kemasan. Adapun tujuan penelitian ini adalah untuk membandingkan antara perhitungan harga pokok produk yang ditetapkan oleh pihak perusahaan dengan perhitungan menggunakan metode harga pokok proses. Apabila dibandingkan dengan harga pokok produksi yang digunakan dengan perhitungan pada perusahaan memberikan hasil yang berbeda yaitu lebih besar menggunakan harga pokok proses. Hal ini disebabkan karena perhitungan yang dilakukan pada perusahaan belum tepat dalam membebankan biaya overhead pabrik ke setiap produknya.
\end{abstract}

Kata Kunci: harga pokok produksi (HPP), metode harga pokok proses

\begin{abstract}
Es Abadi Sorong is a private company engaged in manufacturing, which produces ice cilinder and shaved ice in packaging. The purpose of this study was to compare the calculation of the cost of products specified by the company with the calculation using the cost methrt. When compared to the cost of production is used by the company's calculations give differer results, namely a greater use of the cost of the process. This is because the calculation is performed at the company have not been right in the factory overhead charge to each product.
\end{abstract}

Keywords: cost of production (HPP), the cost method process

\section{PENDAHULUAN}

\subsection{Latar Belakang}

Perusahaan manufaktur merupakan salah satu jenis perusahaan yang didirikan dengan tujuan untuk memperoleh laba. Demi mencapai tujuan tersebut, berbagai cara dilakukan oleh pihak manajemen perusahaan dalam mengelola perusahaan. Salah satunya adalah berupaya untuk selalu tepat dalam mengambil keputusan. Pengambilan keputusan yang tepat didasari oleh informasi yang tepat dan untuk memperoleh informasi yang tepat, manajemen perusahaan memerlukan akuntansi sebagai alat yang dapat membantu dalam penyediaan informasi, khususnya informasi keuangan.

Penentuan harga pokok produksi merupakan hal yang sangat penting mengingat manfaat informasi harga pokok produksi adalah untuk menentukan harga jual produk, pemantauan realisasi biaya produksi, perhitungan laba rugi periodik serta penentuan harga pokok persediaan produk jadi dan produk dalam proses yang akan disajikan dalam neraca.

Menurut Drs. Mulyadi, M.Sc., (2010) menjelaskan bahwa biaya adalah pengorbanan yang harus dikeluarkan oleh perusahaan untuk memproduksi atau menghasilkan barang maupun jasa. Menurut Drs. Mulyadi, M.Sc., (2010) biaya disebut sebagai biaya harga pokok atau harga pokok produksi. Untuk menentukan besarnya biaya tersebut haruslah tepat dan akurat sehingga harga pokok yang terjadi juga akan menunjukkan harga pokok yang sesungguhnya. Dalam memperhitungkan unsurunsur biaya ke dalam harga pokok produksi, terdapat dua pendekatan yaitu full costing dan variable costing. Full costing merupakan metode penentuan harga pokok produksi yang memperhitungkan semua unsur biaya produksi ke dalam harga pokok produksi yang terdiri dari biaya bahan baku, biaya tenaga kerja langsung, dan biaya overhead pabrik baik yang berperilaku variabel maupun tetap. Sedangkan variable costing merupakan metode penentuan harga pokok produksi yang terdiri dari biaya 
bahan baku, biaya tenaga kerja langsung, dan biaya overhead pabrik variabel.

Pabrik Es Batu "Es Abadi" merupakan perusahaan perseorangan yang bergerak dalam bidang manufaktur diketahui bahwa dalam perhitungan harga pokok produksi masih menggunakan perhitungan yang sederhana karena masih ada biaya overhead pabrik yang belum diperhitungkan dalam penentuan harga pokok produksi. Hal ini terjadi karena tidak terperincinya dalam menghitung biaya produksi. Pabrik Es Batu "Es Abadi" belum sepenuhnya memperhatikan biaya overhead pabrik. Pabrik Es Batu "Es Abadi" hanya berfokus pada biaya bahan baku, biaya tenaga kerja dan biaya overhead pabrik yang terdiri dari biaya listrik dan biaya ganti oli mesin produksi. Sedangkan biaya-biaya yang dikeluarkan Pabrik Es Batu "Es Abadi" tidak hanya biaya bahan baku dan biaya tenaga kerja saja, tetapi masih ada biaya overhead pabrik yang belum diperhitungkan. Berdasarkan latar belakang yang telah diuraikan diatas maka penulis tertarik untuk mengetahui bagaimana PENENTUAN HARGA POKOK PRODUKSI ES CILINDER DAN ES SERUT yang diterapkan pada Pabrik Es Batu "ES ABADI SORONG" dengan prosedur akuntansi yang benar.

\section{TINJAUAN PUSTAKA}

\subsection{Pengertian Biaya}

Konsep dan pemahaman tentang biaya sangat penting terutama dalam penerapan akuntansi biaya untuk menghitung harga pokok produksi. Biaya secara garis besar merupakan harga perolehan yang dikorbankan atau digunakan dalam rangka memperoleh penghasilan dan akan dipakai sebagai pengurangan penghasilan. Pemahaman tentang biaya sangat penting terutama dalam penerapan pada suatu perusahaan yang melakukan perhitungan harga pokok produksi.

Menurut Dr. R.A. Supriyono, S.U., Akuntan (2012). Biaya adalah harga perolehan yang dikorbankan atau digunakan dalam rangka memperoleh penghasilan (revenus) dan akan dipakai sebagai pengurang penghasilan. Biaya digolongkan ke dalam harga pokok penjualan, biaya penjualan, biaya administrasi dan umum, biaya bunga dan biaya pajak perseroan.

\subsection{Penggolongan Biaya}

Menurut Drs. Mulyadi,M.Sc. (2014). Biaya digolongkan dengan berbagai macam cara. Umumnya penggolongan biaya ini ditentukan atas dasar tujuan yang hendak dicapai dengan penggolongan tersebut, karena dalam akuntasi biaya di kenal konsep: "different costs for different purposes".

Biaya dapat digolongkan menurut :

1. Objek pengeluaran.

2. Fungsi pokok dalam perusahaan.

3. Hubungan biaya dengan sesuatu yang dibiayai.

4. Perilaku biaya dalam hubungan dengan perubahan volume kegiatan.

5. Jangka waktu manfaatnya.

\subsubsection{Penggolongan Biaya Menurut Objek Pengeluaran}

Penggolongan biaya menurut objek pengeluaran yaitu, nama objek pengeluaran merupakan dasar penggolongan biaya. Misalnya nama objek pengeluaran adalah bahan bakar, maka semua pengeluaran yang berhubungan dengan bahan bakar disebut "biaya bahan bakar"

Contoh penggolongan biaya atas dasar objek pengeluaran dalam perusahaan kertas adalah sebagai berikut: biaya merang, biaya jerami, biaya gaji dan upah, biaya soda, biaya depresiasi mesin, biaya asuransi, biaya bunga, biaya zat warna.

\subsubsection{Penggolongan Biaya Menurut Fungsi Pokok dalam Perusahaan}

Dalam perusahaan manufaktur, ada tiga fungsi pokok, yaitu fungsi produksi, fungsi pemasaran, dan fungsi administrasi dan umum. Oleh karena itu dalam perusahaan manufaktur, biaya dapat dikelompokkan menjadi tiga kelompok:

1. Biaya Produksi.

Biaya produksi. Merupakan biaya-biaya yang terjadi untuk mengolah bahan baku menjadi produk jadi yang siap untuk dijual. Contohnya adalah biaya depresiasi mesin dan ekuipmen, biaya bahan baku, biaya bahan penolong, biaya gaji karyawan yang bekerja dalam bagian-bagian baik yang langsung maupun yang tidak langsung berhubungan dengan proses produksi. 
Menurut objek pengeluarannya, secara garis besar biaya produksi ini dibagi menjadi: biaya bahan baku, biaya tenaga kerja langsung dan biaya overhead pabrik.

a) Biaya bahan baku dan biaya tenaga kerja langsung; disebut pula dengan istilah biaya utama.

b) Biaya overhead pabrik; sering pula disebut dengan istilah biaya konversi, yang merupakan biaya untuk mengkonversi (mengubah) bahan baku menjadi produk jadi.

2. Biaya Pemasaran.

Biaya Pemasaran. Merupakan biayabiaya yang terjadi untuk melakukan kegiatan pemasaran produk.

Contohnya adalah biaya iklan, biaya promosi, biaya angkutan dari gudang perusahaan ke gudang pembeli, gaji karyawan bagian-bagian yang melaksanakan kagiatan pemasaran, biaya contoh (sample)

3. Biaya Administrasi dan Umum.

Biaya Administrasi dan Umum. Merupakan biaya-biaya untuk mengkoordinasi kegiatan produksi dan pemasaran produk.

Contoh biaya ini adalah biaya gaji karyawan Bagian Keuangan Akuntansi Personalia dan Bagian Hubungan Masyarakat biaya pemeriksaan akuntan biaya photocopy.

Jumlah biaya pemasaran dan biaya administrasi umum sering pula disebut dengan istilah biaya komersial (commercial expenses).

\subsubsection{Penggolongan Biaya Menurut Hubungan dengan Sesuatu yang Dibiayai}

Penggolongan biaya dapat dikelompokkan menjadi dua golongan, yaitu:

a) Biaya Langsung

Biaya langsung adalah biaya yang terjadi yang penyebab satu-satunya adalah karena adanya sesuatu yang dibiayai.

Contohnya adalah biaya tenaga kerja yang bekerja dalam departemen pemeliharaan dan biaya depresiasi mesin yang dipakai dalam departemen tersebut, merupakan biaya tidak langsung bagi departemen tersebut.

b) Biaya Tidak Langsung

Biaya tidak langsung adalah biaya yang terjadinya tidak hanya disebabkan oleh sesuatu yang dibiayai. Biaya tidak langsung dalam hubungannya dengan produk disebut dengan istilah biaya produksi tidak langsung atau biaya overhead pabrik (factory overhead costs).

Contohnya adalah biaya yang terjadi di Departemen Pembangkit Tenaga Listrik. Biaya ini dinikmati oleh departemen-departemen lain dalam perusahaan, baik untuk penerangan maupun untuk menggerakan mesin dan ekuipmen yang mengkonsumsi listrik. Bagi departemen pamakai listrik, biaya listrik yang diterima dari alokasi biaya Departemen Pembangkit Tenaga Listrik merupakan biaya tidak langsung departemen.

\subsubsection{Penggolongan Biaya Menurut Perilakunya dalam Hubungannya dengan Perubahan Volume Aktivitas}

Dalam hubungannya dengan perubahan volume kegiatan, biaya dapat dikelompokkan menjadi empat golongan, yaitu :

a) Biaya Variable

Biaya variable adalah biaya yang jumlah totalnya berubah sebanding dengan perubahan volume kegiatan.

Contohnya biaya variable adalah biaya bahan baku, biaya tenaga kerja langsung.

b) Biaya Semivariabel

Biaya semivariabel adalah biaya yang berubah tidak sebanding dengan perubahan volume kegiatan. Biaya semivariabel mengandung unsur biaya tetap dan unsur biaya variable.

c) Biaya Semifixed

Biaya semifixed adalah biaya yang tetap untuk tingkat volume kegiatan tertentu dan berubah dengan ju $h$ yang konstan pada volume produksi tertentu. 
d) Biaya tetap

Biaya tetap adalah biaya yang jumlah totalnya tetap dalam kisar volume kegiatan tertentu.

Contohnya biaya tetap adalah gaji direktur produksi.

\subsubsection{Penggolongan Biaya Atas Dasar Jangka Waktu Manfaatnya}

Atas dasar jangka waktu manfaatnya biaya dapat dibagi menjadi dua: pengeluaran modal dan pengeluaran pendapatan.

a) Pengeluaran modal, yaitu biaya yang mempunyai manfaat lebih dari satu periode akuntansi (biasanya periode akuntansi adalah satu tahun kalender). Contoh pengeluaran modal pengeluaran untuk pembelian aktiva tetap, untuk reparasi besar terhadap aktiva tetap, untuk promosi besar-besaran, dan pengeluaran untuk riset dan pengembangan suatu produk.

b) Pengeluaran pendapatan, yaitu biaya yang hanya mempunyai manfaat dalam periode akuntansi terjadinya pengeluaran tersebut.

Contoh pengeluaran pendapatan yang diperoleh antara lain adalah biaya iklan, biaya telex, dan biaya tenaga kerja.

\subsection{Harga Pokok Produksi}

Harga pokok adalah istilah yang digunakan pada akuntansi keuangan untuk menggambarkan biaya langsung yang timbul dari barang yang diproduksi dan dijual dalam kegiatan bisnis. Harga pokok juga merupakan elemen penting untuk menilai keberhasilan dari perusahaan dagang maupun manufaktur. Harga pokok mempunyai kaitan erat dengan indikatorindikator keberhasilan perusahaan, seperti misalnya laba kotor penjualan dan laba bersih.

Adapun beberapa pengertian harga pokok menurut para ahli di bidang Akuntansi, yaitu sebagai berikut :

Menurut Dr. R.A. Supriyono, S.U., Akuntan (2012). Harga perolehan atau harga pokok adalah jumlah yang dapat diukur dalam satuan uang dalam bentuk, kas yang dibayarkan, nilai aktiva lainnya yang diserahkan/ dikorbankan,nilai jasa yang diserahkan/ dikorbankan, hutang yang timbul atau tambahan modal.

\subsection{Penentuan Harga Pokok}

Penetuan harga pokok adalah bagaimana memperhitungkan biaya kepada suatu produk atau pesanan atau jasa, yang dapat dilakukan dengan cara memasukkan seluruh biaya produksi atau hanya memasukkan unsur biaya variable saja. Dalam penentuan harga pokok tersebut dapat digunakan dua cara yaitu :

1. Metode Kalkulasi Biaya Penuh (full costing)

Kalkulasi biaya penuh adalah suatu metode dalam penentuan harga pokok suatu produk dengan memperhitungkan semua biaya produksi, seperti biaya bahan baku langsung, tenaga kerja langsung, biaya overhead pabrik variable dan biaya overhead pabrik tetap.

2. Metode Kalkulasi Biaya Penuh (variable costing)

Kalkulasi biaya variable adalah suatu metode dalam penentuan harga pokok suatu produk, hanya memperhitungkan biaya produksi yang bersifat variable saja seperti biaya bahan baku langsung, tenaga kerja langsung dan overhead pabrik tetap tidak diperhitungkan sebagai biaya produksi tetapi biaya overhead tetap akan diperhitungkan sebagai biaya periode yang akan dibebankan dalam laporan laba rugi tahun berjalan.

\subsection{Metode Pengumpulan Harga Pokok}

Menurut Dr. R.A. Supriyono, S.U., Akuntan (2012). Secara ekstrim pola pengumpulan harga pokok dapat dikelompokkan menjadi dua metode yaitu :

1. Metode Harga Pokok Pesanan (Job Order Cost Method)

Metode harga pokok pesanan adalah metode pengumpulan harga pokok produk di mana biaya dikumpulkan untuk setiap pesanan atau kontrak atau jasa secara terpisah, dan setiap pesanan atau kontrak dapat dipisahkan identitasnya. Pengolahan produk akan dimulai setelah datangnya pesanan dari langganan/ pembeli melalui dokumen pesanan penjualan (sales order), yang memuat jenis dan jumlah produk yang dipesan, spesifikasi pesanan, tanggal pesanan diterima dan harus diserahkan. 
Atas dasar pesanan penjualan akan dibuat perintah produksi (production order) untuk melaksanakan kegiatan produksi sesuai dengan yang dipesan oleh pembeli.

Dari uraian diatas dapat disimpulkan bahwa tujuan produksi untuk melayani pesanan dari sifat produksinya akan terputus-putus, selesai diolah pesanan yang satu dilanjutkan pengolahan pesanan yang lainnya.

Pada harga pokok pesanan, harga pokok dikumpulkan untuk setiap pesanan sesuai dengan biaya yang dinikmati oleh setiap pesanan, jumlah biaya produksi setiap pesanan akan dihitung pada saat pesanan selesai. Untuk menghitung biaya satuan, jumlah biaya produksi pesanan tertentu dibagi jumlah produksi pesanan yang bersangkutan.

Contoh perusahaan yang berproduksi atau menghasilkan jasa atas dasar pesanan misalnya perusahaan percetakan, kontraktor bangunan, kantor akuntan atau konsultan, pabrik botol dan sebagainya.

2. Meode Harga Pokok Proses (process cost method).

Metode harga pokok proses adalah metode pengumpulan harga pokok produk dimana biaya dikumpulkan untuk setiap satuan waktu tertentu, misalnya bulan, triwulan, semester, tahun.

Pada metode harga pokok proses perusahaan menghasilkan produk yang homogin, bentuk produk bersifat standar dan tidak tergantung spesifikasi yang diminta oleh pembeli.

Kegiatan produksi perusahaan ditentukan oleh budget produksi atau skedul produksi untuk satuan waktu tertentu yang sekaligus dipakai dasar oleh bagian produksi untuk mengisi melaksanakan produksi.

Tujuan produksi untuk mengisi persediaan yang selanjutnya akan dijual kepada pembeli, oleh karena sifat produk homogin dan bentuknya standar maka kegiatan produksi dapat dilaksanakan secara kontinyu atau terus-menerus. Jumlah produk total biaya pada harga pokok proses dihitung setiap akhir periode dengan menjumlah semua elemen biaya yang dinikmati produk dalam satuan waktu yang bersangkutan. Untuk menghitung biaya, jumlah total biaya produksi pada satuan waktu tertentu dibagi jumlah produk yang dihasilkan pada satuan waktu yang sama. Contoh perusahaan yang menghasilkan produk atau jasa atas dasar proses misalnya: pabrik semen, kertas, petrokimia, tekstil, penyulingan minyak mentah, PLN, air minum, perusahaan angkutan dan sebagainya.

Dalam praktek suatu perusahaan dapat menggunakan kombinasi metode harga pokok proses dan metode harga pokok pesanan bersama-sama, misalnya pada perusahaan meubel di samping melayani pesanan juga membuat meubel untuk persedianan yang kemudian dijual, pada perusahaan modiste atau konfeksi di samping melayani pesanan juga membuat produk untuk persediaan yang kemudian dijual.

Penerapan metode tersebut pada suatu perusahaan tergantung pada sifat atau karakteristik pengolahan menjadi produk selesai yang akan mempengaruhi metode pengumpulan harga pokok yang digunakan.

\subsection{Aliran Kegiatan Perusahaan Manufaktur dan Aliran Harga Pokok Produk}

Aliran harga pokok produk menunjukkan aliran biaya produksi dalam rangka kegiatan pengolahan bahan baku menjadi produk selesai yang selanjutnya dijual, oleh karena itu aliran harga pokok produk akan dipengaruhi atau tergantung aliran kegiatan perusahaan manufaktur dalam mengolah bahan baku menjadi produk selesai yang kemudian dijual adalah sebagai berikut :

a) Pengadaan

Pengadaan adalah kegiatan untuk memperoleh atau mengadakan barang dan jasa yang akan dikonsumsi dalam kegiatan produksi, dapat dikelompokkan ke dalam :

1. Pembelian, penerimaan, dan penyimpanan bahan baku, bahan penolong, supplies pabrik dan 
elemen (barang) lainnya yang akan dikonsumsi dalam kegiatan

2. Perolehan jasa dari tenaga kerja langsung, tenaga kerja tidak langsung dan jasa lainnya yang akan dikonsumsi dalam kegiatan produksi.

b) Produksi

Produksi adalah kegiatan pengolaha bahan baku menjadi produk selesai. Pada kegiatan tersebut akan dikonsumsi bahan baku, tenaga kerja langsung barang dan jasa lainnya yang dikelompokkan dalam overhead pabrik.

c) Penyimpanan produk selesai

Produk yang telah selesai diproduksi dari pabrik akan dipindahkan ke dalam gudang produk selesai menunggu saat di jual atau diserahkan kepada pemesan.

d) Penjualan produk selesai

Produk yang sudah laku dijual akan dikeluarkan dari gudang produk selesai untuk dikirim kepada pembeli, dan perusahaan dapat membebani rekening langganan atau pembeli.

\subsection{Sistem Pembebanan Biaya pada Metode Harga Pokok Proses}

Menurut Dr. R.A. Supriyono, S.U., Akuntan (2012). Dihubungkan dengan pembebanan harga pokok kepada produk, metode harga pokok proses dapat menggunakan sistem :

a) Semua elemen biaya dibebankan berdasarkan biaya sesungguhnya. Pada sistem ini, produk yang diolah dibebani biaya bahan, biaya tenaga kerja, dan biaya overhead pabrik yang sesungguhnya dinikmati oleh produk yang bersangkutan.

b) Elemen biaya tertentu yaitu biaya overhead pabrik, dibebankan berdasarkan tarip atau biaya yang ditentukan dimuka.

c) Semua elemen biaya dibebankan pada produk atas dasar harga pokok yang ditentukan dimuka.

\subsection{Manfaat Perhitungan Harga Pokok Proses}

Penentuan harga pokok produksi sangat bermanfaat untuk :

a) Menentukan harga jual produk

b) Memantau realisasi biaya produksi c) Menghitung laba atau rugi periodik

d) Menentukan harga pokok persediaan produk jadi dan produk produk dalam proses yang disajikan dalam neraca.

\subsection{Manfaat Perhitungan Harga Pokok Per Pesanan}

Penentuan harga pokok produksi sangat bermanfaat untuk :

a) Menentukan harga jual yang akan dibebankan kepada pemesan

b) Mempertingkan penerimaan atau penolokan pesanan

c) Memantau realisasi biaya produksi

d) Menghitung laba atau rugi tiap pesanan

e) Menentukan harga pokok persediaan produk jadi dan produk dalam proses yang disajikan dalam neraca.

\subsection{Metode Harga Pokok Pesanan}

Menurut Drs. R.A. Supriyono,S.U., Akt Metode Harga Pokok Pesanan adalah metode pengumpulan harga pokok produk dimana biaya dikumpulkan untuk setiap pesanan atau kontrak atau jasa secara terpisah dan dipisahkan identitasnya.

1. Karakteristik Metode Harga Pokok Pesanan

a) Sifat proses produksi yang dilakukan terputus-putus dan tergantung pada pesanan yang diterima.

b) Spesifikasi dan bentuk produk tergantung pada pemesan.

c) Pencatatan biaya produksi masingmasing pesanan dilakukan pada kartu biaya pesanan secara terperinci untuk masing-masing pesanan.

d) Total biaya produksi untuk setiap elemen dikalkulasi setelah pesanan selesai.

e) Biaya perunit dihitung, dengan membagi total biaya produksi yang terdiri dari: bahan baku langsung, tenaga kerja langsung dan biaya overhead dibebankan dengan total unit yang dipesan.

f) Akumulasi biaya pada umumnya menggunakan biaya normal.

g) Produk yang sudah selesai dapat disimpan digudang atau langsung diserahkan pada pemesan.

2. Prosedur Akuntansi Biaya pada Metode Harga Pokok Pesanan

Prosedur akuntansi biaya pada metode harga pokok pesanan meliputi organisasi formulir, catatan-catatan dan laporan- 
laporan yang terkoordinasi dalam rangka melaksanakan kegiatan untuk melayani pesanan dan menyajikan informasi biaya bagi manajemen. Dalam hal ini prosedur akuntansi biaya dapat dikelompokkan sebagai berikut :

a) Prosedur akuntansi biaya bahan dan supplies.

b) Prosedur akuntansi biaya tenaga kerja.

c) Prosedur akuntansi biaya overhead pabrik.

d) Prosedur akuntansi produk selesai dan produk dalam proses akhir periode.

e) Prosedur akuntansi penjualan dan penyerahan produk kepada pemesan.

\subsection{Metode Harga Pokok Proses}

Metode harga pokok proses adalah metode pengumpulan harga pokok produk dimana biaya dikumpulkan untuk setiap satuan waktu tertentu, misalnya bulan, triwulan, semester, tahun. Pada metode ini perusahaan menghasilkan produk yang homogen, bentuk produk bersifat standar, dan tidak tergantung spesifikasi yang diminta oleh pembeli.

1. Karakteristik Metode Harga Pokok Proses, yaitu :

a) Biaya dikumpulkan untuk setiap satuan waktu tertentu, misalnya bulan, tahun dan sebagainya.

b) Produk yang dihasilkan bersifat homogin dan bentuknya standar, tidak tergantung spesifikasi yang diminta oleh pembeli.

c) Kegiatan produksi didasarkan pada budget produksi atau schedule produksi untuk satuan waktu tertentu.

d) Tujuan produksi untuk mengisi persediaan yang selanjutnya dijual.

e) Kegiatan produksi bersifat continue atau terus-menerus

f) Jumlah total biaya maupun biaya satuan dihitung setiap akhir periode, misalnya akhir bulan, akhir tahun.

2. Karakteristik Utama dari Metode Harga Pokok Proses adalah sebagai berikut :

a) Laporan harga pokok produksi digunakan untuk mengumpulkan, meringkas dan menghitung harga pokok baik total maupun satuan atau per unit. Apabila produk diolah melalui beberapa tahap atau departemen, laporan harga pokok disusun setiap departemen di mana produk diolah. b) Biaya produksi periode tertentu dibebankan kepada produk melalui rekening barang dalam proses yang diselenggarakan untuk setiap elemen biaya. Apabila produk diolah melalui beberapa departemen, rekening barang dalam proses disamping diselenggarakan untuk setiap elemen biaya harus diselenggarakan untuk setiap departemen dimana produk diproses.

c) Produksi dikumpulkan dan dilaporkan untuk satuan waktu atau periode tertentu. Apabila produk diproses melalui beberapa tahap atau departemen, laporan produksi tersebut dibuat untuk departemen.

d) Produksi ekuivalen digunakan untuk menghitung harga pokok satuan. Produksi ekuivalen adalah tingkatan atau jumlah produksi dimana pengolahan produk dinyatakan dalam ukuran produk selesai.

e) Untuk menghitung harga pokok satuan setiap elemen biaya produksi tertentu, maka elemen biaya produksi tertentu (misalnya bahan baku) tersebut dibagi dengan produksi ekuivalen untuk elemen biaya yang bersangkutan (produksi ekuivalen bahan).

f) Harga pokok yang diperhitungkan untuk mengetahui elemen-elemen yang menikmati biaya yang dibebankan, beberapa yang dinikmati produk selesai dari departemen tertentu atau pengolahan yang dipindahkan kegudang atau kedepartemen berikutnya dan berapa harga pokok produk dalam proses akhir.

g) Apabila dalam proses pengolahan produk timbul produk hilang, produk rusak, produk cacat tambahan produk akan diperhitungkan pengaruhnya dalam perhitungan harga pokok produk.

3. Prosedur Akuntansi Biaya Pada Metode Harga Pokok Proses.

a) Mengumpulkan data produksi untuk menyusun laporan produksi dan menghitung produksi ekuivalen dalam rangka menghitung harga pokok satuan.

b) Mengumpulkan biaya bahan, biaya tenaga kerja, dan biaya overhead pabrik periode tertentu. Apabila produk diproses melalui beberapa departemen elemen biaya tersebut dikumpulkan untuk setiap departemen. 
c) Menghitung harga pokok satuan setiap elemen biaya, yaitu jumlah elemen biaya tertentu dibagi produksi ekuivalen dari elemen biaya yang bersangkutan.

d) Menghitung harga pokok produk selesai yang dipindahkan ke gudang atau departemen berikutnya dan menghitung harga pokok produk dalam proses akhir.

Media yang dipakai dalam menghitung atau menentukan harga pokok produk adalah Laporan Harga Pokok Produksi yang membuat informasi sebagai berikut :

a. Laporan Produksi

Bagian laporan ini menunjukkan :

1. Informasi jumlah produk yang diolah, baik dari produk dalam proses awal, produk yang baru dimasukkan atau diterima dari departemen sebelumnya, maupun tambahan produk pada departemen lanjutan akibat adanya tambahan bahan kalau ada.

2. Informasi jejak produk yang diolah, meliputi produk selesai yang dimasukkan ke gudang atau dipindahkan ke departemen lanjutan, produk rusak, produk cacat kalau ada.

b. Biaya Yang Dibebankan

Bagian laporan ini menunjukan informasi tentang :

1. Jumlah biaya yang dibebankan meliputi harga pokok dalam proses awal kalau ada, harga pokok yang diterima dari departemen sebelumnya untuk departemen lanjutan, dan elemen biaya yang ditambahkan pada tahap pengolahan produk yang bersangkutan.

2. Tingkat produksi ekuivalen yang dihitung dari laporan produksi informasi ini berguna untuk menghitung harga pokok satuan.

3. Harga pokok satuan untuk setiap elemen biaya yang dibebankan pada tahap pengolahan produk atau departemen yang bersangkutan.

c. Perhitungan Harga Pokok

Bagian laporan ini memberikan informasi tentang jejak biaya yang dibebankan, menunjukan berapa biaya yang diserap oleh harga pokok produk selesai maupun produk dalam proses pada akhir periode dan sebagainya.

d. Penggolongan Biaya pada Metode Harga Pokok Proses
Dalam akuntansi biaya untuk metode harga pokok proses biaya produksi digolongkan sebagai berikut :

a) Biaya Bahan

Dalam metode harga pokok proses tidak diadakan pemisahan antara bahan baku dan bahan penolong, hal ini disebabkan umumnya produk yang dihasilkan bersifat homogin dan bentuknya standar sehingga setiap satuan produk yang sama akan menikmati bahan relatif sama pula. Semua harga pokok bahan yang diproses menjadi produk selesai baik dapat diidentifikasikan atau tidak dapat diidentifikasikan dengan produk tertentu, adalah merupakan biaya bahan.

b) Biaya Tenaga Kerja

Dalam metode harga pokok proses tidak dipisahkan atau dibedakan antara biaya tenaga kerja langsung dan biaya tenaga kerja tidak langsung. Apabila produk diolah melalui. satu tahapan pengolahan, maka semua biaya tenaga kerja di pabrik digolongkan sebagai elemen biaya tenaga kerja, dari daftar gaji dan upah untuk produksi dibuat jurnal sebagai berikut :

c) Biaya Overhead Pabrik

Dari uraian penggolongan biaya bahan dan biaya tenaga kerja tersebut di atas dapat ditarik kesimpulan pengertian biaya overhead pabrik. Biaya overhead pabrik pada metode harga pokok proses, yaitu meliputi semua biaya produksi selain biaya bahan dan biaya tenaga kerja.

\section{METODE PENELITIAN}

\subsection{Tempat dan Objek Penelitian}

Dalam pelaksanaan penelitian, yang menjadi lokasi penelitian di Pabrik Es Batu Dalam Kemasan "Es Abadi Sorong". Waktu penelitian yang dilakukan oleh penulis adalah dalam waktu dua bulan, yaitu dari bulan Mei sampai dengan Juni 2016.

\subsection{Teknik Pengumpulan Data}

1. Observasi

Dalam mengumpulkan data yang diperlukan dalam penelitian penulis melakukan observasi yaitu melakukan kunjungan atau pengamatan secara 
langsung pada objek penelitian untuk mendapatkan keterangan yang diperlukan, selain itu penulis juga melakukan wawancara dengan cara mengadakan tanya jawab langsung dengan pimpinan perusahaan mengenai data yang ada sesuai dengan masalah yang akan dibahas, serta menggunakan arsip atau dokumendokumen yang bersifat tulisan dari perusahaan yang bersangkutan.

2. Wawancara

Metode pengumpulan data ini dengan metode wawancara kepada pengawas umum dan bagian produksi, Pabrik Es Batu Dalam Kemasan "Es Abadi" untuk memberikan keterangan-keterangan yang berkaitan dengan permasalahan yang ada di dalam penelitian ini.

3. Studi pustaka

Metode pengumpulan data dengan cara mempelajari literatur-literatur dan sumbersumber tertulis lainnya yang berhubungan dengan masalah yang akan diteliti dalam penulisan skripsi ini.

\subsection{Jenis dan Sumber Data}

Jenis data yang digunakan dalam penelitian ini adalah:

1. Kuantitatif, yaitu data dalam bentuk angkaangka seperti informasi biaya dan data-data yang berhubungan dengan masalah yang akan dibahas.

2. Kualitatif, yaitu data yang diperoleh dari objek penelitian dalam bentuk informasi baik secara lisan maupun tulisan seperti struktur organisasi, pembagian tugas, dan lain-lain.

Sumber data yang digunakan dalam penelitian ini adalah:

1. Data primer yaitu data yang dikumpulkan sendiri oleh peneliti dari objek penelitian. Data jenis ini berasal dari observasi, wawancara dan konsultasi terhadap pihakpihak yang bersangkutan.

2. Data sekunder yaitu data yang diperoleh dari sumber-sumber tertulis berupa data keuangan serta data pendukung lainnya yang berkaitan dengan masalah yang dibahas dalam penulisan ini.

\subsection{Metode Analisis Data}

Metode analisis data yang digunakan dalam penulisan laporan ini adalah analisis data deskriptif. Metode deskriptif merupakan suatu cara penelitian yang menggambarkan atau menguraikan keadaan dari objek penelitian (perusahaan) berdasarkan faktor-faktor yang nyata di situasi yang akan diteliti dan membandingkan dengan teori akuntansi yang ada.

$$
\text { Langkah-langkah analisis dalam }
$$
penelitian ini antara lain :

1. Mencantumkan harga pokok produksi es cilinder dan es serut pada Es Abadi Sorong dengan menggunakan metode harga pokok proses

2. Mengidentifikasi elemen-elemen biaya

3. Membebankan biaya overhead pabrik

4. Membandingkan antara perhitungan harga pokok produksi es cilinder dan es serut dengan perhitungan harga pokok produksi es cilimder dan es serut hasil analisis.

\section{PEMBAHASAN}

\subsection{Perhitungan Harga Pokok Produksi Pada Es Abadi Sorong}

Perhitungan harga pokok produksi yang tepat dan teliti sangat diperlukan oleh manajemen perusahaan karena merupakan faktor penting didalam menentukan harga jual, memantau biaya produksi, dan sebagai alat penetapan keputusan. Harga pokok produksi sangatlah penting bagi Es Abadi karena harga pokok produksi berfungsi sebagai informasi dalam penetapan keputusan khususnya dalam penetapan harga jual suatu produk.

Dari hasil pengamatan dan penelitian yang dilakukan terhadap metode penentuan harga pokok produk yang dilakukan oleh perusahaan, penulis menemukan ada beberapa biaya produksi yang tidak dihitung secara terperinci oleh perusahaan dalam kalkulasi perhitungan harga pokok produksi yaitu biaya overhead pabrik. Sehingga dalam perhitungannya biaya overhead menurun dan harga pokok produksi menjadi lebih rendah dari harga yang sebenarnya. Maka dengan ini penulis ingin menggunakan metode harga pokok proses untuk menghitung harga pokok es celinder dan es serut pada Es Abadi Sorong.

\subsubsection{Elemen-elemen Harga Pokok Produksi Pada Es Abadi Sorong Elemen-elemen harga pokok produksi adalah semua biaya yang dikeluarkan untuk}


memproduksi suatu barang yang dikelompokkan menjadi tiga elemen biaya yaitu : biaya bahan baku, biaya tenaga kerja, dan biaya overhead pabrik.

1. Biaya Bahan

Bahan merupakan bagian yang secara menyeluruh membentuk produk dan dapat diidenfikasikan secara langsung pada produk yang bersangkutan. Pengadaan dan penyediaan serta pemakaian bahan merupakan bagian yang penting bagi perusahaan manufaktur dalam melaksanakan proses produksi, karena bahan merupakan komponen yang paling utama yang diolah menjadi produk selesai dalam setiap perusahaan manufaktur.

Tabel 4.1

Biaya Bahan

Es Abadi Sorong

\begin{tabular}{|l|lr|}
\hline \multicolumn{1}{|c|}{ Bulan } & \multicolumn{2}{|c|}{ B iaya Bahan Baku } \\
(Air)
\end{tabular}

Sumber : Es Abadi Sorong 2015

Biaya bahan baku air diperoleh dari jumlah pemakaian/ hari 10.000 liter dengan harga 250.000/ 5.000 liter. kerja

Biaya bahan baku $=\operatorname{Rp} 500.000 *$ hari

Dari 10.000 liter air dihasilkan $7.000 \mathrm{~kg}$ es, yang terbagi dalam dua bentuk yaitu :

a) Es Cilinder $4000 \mathrm{~kg}$

b) Es Serut $3000 \mathrm{~kg}$

\section{Biaya Tenaga Kerja}

Biaya tenaga kerja adalah suatu balas jasa yang diberikan oleh perusahaan kepada semua karyawan pabrik yang dapat diidentifikasikan pada produksi tertentu yang dapat dihasilkan perusahaan.

Tabel 4.2

Biaya Tenaga Kerja

Es Abadi Sorong

\begin{tabular}{|l|c|ll|}
\hline Keterangan & $\begin{array}{c}\text { Gaji } \\
\text { Pokok/orang }\end{array}$ & \multicolumn{2}{|c|}{ Total Gaji } \\
\hline Januari & $\mathrm{Rp} 2.015 .000$ & $\mathrm{Rp}$ & 22.165 .000 \\
Februari & $\mathrm{Rp} 2.015 .000$ & $\mathrm{Rp}$ & 22.165 .000 \\
Maret & $\mathrm{Rp} 2.015 .000$ & $\mathrm{Rp}$ & 22.165 .000 \\
April & $\mathrm{Rp} 2.015 .000$ & $\mathrm{Rp}$ & 22.165 .000 \\
Mei & $\mathrm{Rp} 2.015 .000$ & $\mathrm{Rp}$ & 22.165 .000 \\
Juni & $\mathrm{Rp} 2.015 .000$ & $\mathrm{Rp}$ & 22.165 .000 \\
Juli & $\mathrm{Rp} 2.015 .000$ & $\mathrm{Rp}$ & 22.165 .000 \\
Agustus & $\mathrm{Rp} 2.015 .000$ & $\mathrm{Rp}$ & 22.165 .000 \\
September & $\mathrm{Rp} 2.015 .000$ & $\mathrm{Rp}$ & 22.165 .000 \\
Oktober & $\mathrm{Rp} 2.015 .000$ & $\mathrm{Rp}$ & 22.165 .000 \\
November & $\mathrm{Rp} 2.015 .000$ & $\mathrm{Rp}$ & 22.165 .000 \\
Desember & $\mathrm{Rp} 2.015 .000$ & $\mathrm{Rp}$ & 22.165 .000 \\
\hline \multicolumn{3}{|l|}{ Total } & $\mathrm{Rp} \mathbf{2 6 5 . 9 8 0 . 0 0 0}$ \\
\hline
\end{tabular}

Gaji karyawan sebesar UMP (Upah Minimum Provinsi) / bulan

Perhitungan Total Gaji merupakan perhitungan gaji untuk 11 orang karyawan Total Gaji $=\operatorname{Rp} 2.015 .000 \times 11$ orang karyawan $=\operatorname{Rp} 22.165 .000 /$ bulan

Total Gaji $/$ Tahun $=$ Rp $22.165 .000 \times 12$ bulan = Rp 265.980.000

a. Bagian produksi berjumlah 4 orang karyawan terdiri dari :

1. Pembungkusan es ke dalam kantong plastik

2. Pengikatan plastik es

3. Pelubangan plastik es

4. Penyimpanan es dalam freezer.

b. Bagian penjualan berjumlah 6 orang karyawan terdiri dari :

1. Untuk sopir 3 orang karyawan

2. Untuk helper 3 orang karyawan

c. Bagian pengawas umum 1 orang karyawan.

3. Biaya Overhead Pabrik

Perhitungan BOP pada Es Abadi hanya memasukkan biaya listrik \& biaya solar . 
Tabel 4.3

Biaya Listrik

Es Abadi Sorong

\begin{tabular}{|l|ll|}
\hline \multicolumn{1}{|c|}{ Bulan } & \multicolumn{2}{|c|}{ Biaya /bulan } \\
\hline Januari & $\mathrm{Rp}$ & $31.756 .372,00$ \\
Februari & $\mathrm{Rp}$ & $30.335 .700,00$ \\
Maret & $\mathrm{Rp}$ & $31.302 .483,00$ \\
April & $\mathrm{Rp}$ & $31.612 .917,00$ \\
Mei & $\mathrm{Rp}$ & $33.055 .799,00$ \\
Juni & $\mathrm{Rp}$ & $37.155 .412,00$ \\
Juli & $\mathrm{Rp}$ & $31.200 .000,00$ \\
Agustus & $\mathrm{Rp}$ & $27.493 .720,00$ \\
September & $\mathrm{Rp}$ & $18.659 .382,00$ \\
Oktober & $\mathrm{Rp}$ & $31.880 .380,00$ \\
November & $\mathrm{Rp}$ & $32.472 .808,00$ \\
Desember & $\mathrm{Rp}$ & $33.271 .900,00$ \\
\hline \multicolumn{2}{|c}{ Total } & \multicolumn{2}{|c|}{ Rp370.196.873,00 } \\
\hline
\end{tabular}

Sumber: Es Abadi Sorong 2015

Tabel 4.4

Biaya Solar

\begin{tabular}{|l|lr|}
\hline \multicolumn{1}{|c|}{ Bulan } & \multicolumn{2}{|c|}{ Biaya/bulan } \\
\hline Januari & $\mathrm{Rp}$ & 3.600 .000 \\
Februari & $\mathrm{Rp}$ & 3.600 .000 \\
Maret & $\mathrm{Rp}$ & 3.600 .000 \\
April & $\mathrm{Rp}$ & 3.600 .000 \\
Mei & $\mathrm{Rp}$ & 3.600 .000 \\
Juni & $\mathrm{Rp}$ & 3.600 .000 \\
Juli & $\mathrm{Rp}$ & 3.600 .000 \\
Agustus & $\mathrm{Rp}$ & 3.600 .000 \\
September & $\mathrm{Rp}$ & 3.600 .000 \\
Oktober & $\mathrm{Rp}$ & 3.600 .000 \\
November & $\mathrm{Rp}$ & 3.600 .000 \\
Desember & $\mathrm{Rp}$ & 3.600 .000 \\
\hline \multicolumn{1}{|c|}{ Total } & $\mathbf{R p}$ & $\mathbf{4 3 . 2 0 0 . 0 0 0}$ \\
\hline
\end{tabular}

Sumber Data : Es Abadi Sorong

Biaya Solar

Perhitungan biaya solar merupakan perhitungan dari 3 mobil, dalam satu minggu pengisian solar untuk satu mobil $\mathrm{Rp} 300.000 * 4$ minggu $=\mathrm{Rp}$ 3.600.000/ bulan.

Total Solar $/$ Tahun $=\operatorname{Rp} 3.600 .000 * 12$ bulan $=$ Rp 43.200.000

\subsubsection{Perhitungan Harga Pokok Es Celinder Dan Es Serut Dalam Kemasan}

Dari data Es Abadi Sorong, penulis dapat membuat perhitungan harga pokok produksi es cilinder dan es serut dalam kemasan sebagai berikut :

Dalam perhitungan harga pokok produksi Es Abadi Sorong belum memasukkan biaya overhead pabrik secara rinci dan biaya penyusutan mesin produksi dan penyusutan gedung pabrik.

a. Biaya Bahan

\begin{tabular}{|c|c|c|c|c|c|}
\hline & & $\begin{array}{r}\text { Perhitung } \\
\text { Bulan J }\end{array}$ & $\begin{array}{l}4.5 \\
\text { Sorong } \\
\text { Pokok Prod } \\
\text { Pesember } 20\end{array}$ & & \\
\hline Bulan & & Cilinder & Bulan & & Serut \\
\hline Januari & $\mathrm{R}$ & 7.429 .000 & Januari & $\mathrm{Rp}$ & 5.571 .000 \\
\hline Februari & $\mathrm{Rp}$ & 6.858 .000 & Februari & $\mathrm{Rp}$ & 5.142 .000 \\
\hline Maret & $\mathrm{Rp}$ & 7.715 .000 & Maret & $\mathrm{Rp}$ & 5.785 .000 \\
\hline April & $\mathrm{Rp}$ & 7.429 .000 & April & $\mathrm{Rp}$ & 5.571 .000 \\
\hline Mei & $\mathrm{Rp}$ & 7.715 .000 & Mei & $\mathrm{Rp}$ & 5.785 .000 \\
\hline Juni & $\mathrm{Rp}$ & 7.429 .000 & Juni & $\mathrm{Rp}$ & 5.571 .000 \\
\hline Juli & $\mathrm{Rp}$ & 7.143 .000 & Juli & $\mathrm{Rp}$ & 5.357 .000 \\
\hline Agustus & $\mathrm{Rp}$ & 7.715 .000 & Agustus & $\mathrm{Rp}$ & 5.785 .000 \\
\hline September & $\mathrm{Rp}$ & 7.429 .000 & September & $\mathrm{Rp}$ & 5.571 .000 \\
\hline Oktober & $\mathrm{Rp}$ & 7.715 .000 & Oktober & $\mathrm{Rp}$ & 5.785 .000 \\
\hline November & $\mathrm{Rp}$ & 7.429 .000 & November & $\mathrm{Rp}$ & 5.571 .000 \\
\hline Desember & & 7.429 .000 & Desember & $\mathrm{Rp}$ & 5.571 .000 \\
\hline Total & & .435 .000 & Total & & .065 .000 \\
\hline
\end{tabular}

Sumber : Data diolah

b. Biaya Tenaga Kerja Langsung Biaya tenaga kerja langsung terdiri dari 4 orang karyawan bagian produksi es cilinder dan es serut 
Tabel 4.6

Biaya Tenaga Kerja Langsung

\begin{tabular}{|c|c|c|c|}
\hline \multirow{3}{*}{\begin{tabular}{|l} 
Bulan \\
Januari
\end{tabular}} & \multicolumn{2}{|c|}{ Dolaya rella } & \multirow[b]{2}{*}{ Tota Gaji } \\
\hline & Es Cilinder & Es Serut & \\
\hline & $\operatorname{Rp} 4.605 .714$ & $\operatorname{Rp~3.454.286~}$ & $\begin{array}{ll}\mathrm{Rp} & 8.060 .000\end{array}$ \\
\hline Februari & Rp 4.605.714 & Rp 3.454.286 & Rp $\quad 8.060 .000$ \\
\hline Maret & Rp 4.605.714 & Rp 3.454.286 & Rp 8.060 .000 \\
\hline April & Rp 4.605.714 & Rp 3.454.286 & Rp 8.060 .000 \\
\hline Mei & Rp 4.605.714 & Rp 3.454.286 & Rp 8.060 .000 \\
\hline Juni & Rp 4.605.714 & Rp 3.454.286 & Rp $\quad 8.060 .000$ \\
\hline Juli & Rp 4.605.714 & Rp 3.454.286 & Rp $\quad 8.060 .000$ \\
\hline Agustus & Rp 4.605.714 & Rp 3.454.286 & Rp $\quad 8.060 .000$ \\
\hline September & Rp 4.605.714 & Rp 3.454.286 & Rp $\quad 8.060 .000$ \\
\hline Oktober & Rp 4.605.714 & Rp 3.454.286 & Rp $\quad 8.060 .000$ \\
\hline November & Rp 4.605.714 & Rp 3.454.286 & Rp $\quad 8.060 .000$ \\
\hline Desember & Rp 4.605.714 & Rp 3.454.286 & Rp $\quad 8.060 .000$ \\
\hline \multicolumn{3}{|c|}{ Total } & Rp 96.720.000 \\
\hline
\end{tabular}

Sumber : Data diolah

c. Biaya overhead Pabrik

Perhitungan es abadi sorong dalam memasukkan biaya overhead pabrik belum memasukkan biaya plastik, biaya ganti oli mesin, biaya penyusutan mesin produksi dan biaya gedung pabrik.

Tabel 4.7

Biaya Listrik

\begin{tabular}{|c|c|c|c|}
\hline Bulan & Es Cilinder & Es Serut & Biaya /Bulan \\
\hline Januari & Rp 18.146.498 & Rp13.609.874 & Rp $\quad 31.756 .372$ \\
\hline Februari & Rp 17.334.685 & Rp13.001.015 & Rp $\quad 30.335 .700$ \\
\hline Maret & Rp 17.887.134 & Rp13.415.349 & Rp $\quad 31.302 .483$ \\
\hline April & Rp 18.064.524 & Rp13.548.393 & Rp $\quad 31.612 .917$ \\
\hline Mei & Rp 18.889.028 & Rp14.166.771 & Rp $\quad 33.055 .799$ \\
\hline Juni & Rp 21.231.664 & Rp15.923.748 & $\operatorname{Rp} \quad 37.155 .412$ \\
\hline Juli & Rp 17.828.571 & Rp13.371.429 & Rp $\quad 31.200 .000$ \\
\hline Agustus & Rp 15.710.697 & Rp11.783.023 & Rp $\quad 27.493 .720$ \\
\hline September & Rp 10.662.504 & $\operatorname{Rp} 7.996 .878$ & 18.659 .382 \\
\hline Oktober & Rp 18.217.359 & Rp13.663.021 & Rp $\quad 31.880 .380$ \\
\hline November & Rp 18.555 .890 & Rp13.916.918 & Rp $\quad 32.472 .808$ \\
\hline Desember & Rp 19.012.514 & Rp14.259.386 & $\mathrm{Rp} \quad 33.271 .900$ \\
\hline \multicolumn{3}{|c|}{ Total } & Rp 370.196.873 \\
\hline
\end{tabular}

Tabel 4.8

Biaya Ganti Oli Mesin

\begin{tabular}{|l|lr|}
\hline \multicolumn{1}{|c|}{ Bulan } & \multicolumn{2}{|c|}{ Biaya/bulan } \\
\hline $\begin{array}{l}\text { Januari } \\
\text { Februari } \\
\text { Maret } \\
\text { April } \\
\text { Mei } \\
\text { Juni }\end{array}$ & Rp & 750.000 \\
Juli \\
$\begin{array}{l}\text { Agustus } \\
\text { September } \\
\text { Oktober } \\
\text { November } \\
\text { Desember }\end{array}$ & Rp & 750.000 \\
\hline \multicolumn{1}{|c|}{ Total } & Rp & \\
\hline
\end{tabular}

Sumber : Data diolah

\subsubsection{Perhitungan Biaya Bahan Penolong}

Bahan penolong yaitu plastik, pada es abadi untuk biaya plastik dalam 1 tahun dibutuhkan 2x pembelian untuk $50 \mathrm{~kg} /$ bulan dengan harga $\mathrm{Rp} 22.500$,

Tabel 4.9

Biaya Plastik

\begin{tabular}{|l|lr|}
\hline \multirow{2}{*}{ Bulan } & \multicolumn{2}{|c|}{ Biaya /bulan } \\
\hline Januari & $\mathrm{Rp}$ & 22.500 \\
Juli & $\mathrm{Rp}$ & 22.500 \\
\hline Total & $\mathrm{Rp}$ & $\mathbf{4 5 . 0 0 0}$ \\
\hline
\end{tabular}

Sumber : Data diolah

\subsubsection{Biaya Penyusutan Aktiva Tetap Mesin Produksi}

Perhitungan biaya penyusutan aktiva tetap menggunakan metode garis lurus.

Penyusutan $=\frac{\mathrm{HP}-\mathrm{NR}}{\mathrm{n}}$

Keterangan :

HP = Harga Perolehan Aktiva Tetap

$\mathrm{NR}=$ Nilai Residu/ Nilai Sisa

$\mathrm{n}=$ Taksiran Umur Ekonomis Aktiva Tetap 
Biaya Penyusutan Mesin Produksi

Harga Perolehan Mesin Produksi Rp 1.800.000.000

Nilai Residu/ Nilai Sisa Rp -

Taksiran Umur Ekonomis $\quad$ Rp 5 Tahun

Penyusutan $=\frac{\operatorname{Rp~1.800.000.000}}{5}=\mathrm{Rp} \quad 360.000 .000 /$ Tahun

Biaya penyusutan Rp 360.000.000 : 12 bulan.

Tabel 4.10

Biava Penyusutan Mesin Produksi

\begin{tabular}{|c|c|c|c|}
\hline Bulan & Es Cilinder & Es Serut & Jumlah \\
\hline Januari & Rp 17.142.857 & Rp 12.857.143 & Rp 30.000 .000 \\
\hline Februari & Rp 17.142.857 & Rp 12.857.143 & $\operatorname{Rp} \quad 30.000 .000$ \\
\hline Maret & Rp 17.142.857 & Rp 12.857.143 & Rp 30.000 .000 \\
\hline April & Rp 17.142.857 & Rp 12.857.143 & Rp 30.000 .000 \\
\hline Mei & Rp 17.142.857 & Rp 12.857.143 & Rp 30.000 .000 \\
\hline Juni & Rp 17.142.857 & Rp 12.857.143 & Rp 30.000 .000 \\
\hline Juli & Rp 17.142.857 & Rp 12.857.143 & Rp 30.000 .000 \\
\hline Agustus & Rp 17.142.857 & Rp 12.857.143 & Rp 30.000 .000 \\
\hline September & Rp 17.142.857 & Rp 12.857.143 & Rp 30.000 .000 \\
\hline Oktober & Rp 17.142.857 & Rp 12.857.143 & Rp 30.000 .000 \\
\hline November & Rp 17.142.857 & Rp 12.857.143 & Rp 30.000 .000 \\
\hline Desember & Rp 17.142.857 & Rp 12.857.143 & Rp 30.000 .000 \\
\hline \multicolumn{3}{|c|}{ Total } & Rp360.000.000 \\
\hline
\end{tabular}

Sumber : Data diolah
Tabel 4.11

Biaya Penyusutan Gedung Pabrik

\begin{tabular}{|c|c|c|c|}
\hline Bulan & Es Cilinder & Es Serut & Jumlah \\
\hline Januari & Rp 285.714 & Rp 214.286 & 500.000 \\
\hline Februari & Rp 285.714 & Rp 214.286 & 500.000 \\
\hline Maret & Rp 285.714 & Rp 214.286 & 500.000 \\
\hline April & Rp 285.714 & Rp 214.286 & 500.000 \\
\hline Mei & Rp 285.714 & Rp 214.286 & 500.000 \\
\hline Juni & Rp 285.714 & Rp 214.286 & 500.000 \\
\hline Juli & Rp 285.714 & Rp 214.286 & 500.000 \\
\hline Agustus & Rp 285.714 & Rp 214.286 & 500.000 \\
\hline September & Rp 285.714 & Rp 214.286 & 500.000 \\
\hline Oktober & Rp 285.714 & Rp 214.286 & 500.000 \\
\hline November & Rp 285.714 & Rp 214.286 & 500.000 \\
\hline Desember & Rp 285.714 & Rp 214.286 & $\mathrm{Rp} \quad 500.000$ \\
\hline \multicolumn{3}{|c|}{ Total } & Rp 6.000.000 \\
\hline
\end{tabular}

Sumber : Data diolah

\subsubsection{Perhitungan Harga Pokok Produksi Menggunakan Metode Harga Pokok Proses Untuk Menghasilkan 2 Macam Bentuk Es yaitu :}

1. Es cilinder $4000 \mathrm{~kg}$ Perhitungan Harga Pokok Produksi Biaya Bahan, Biaya Tenaga Kerja dan Biaya Overhead Pabrik yaitu dari jumlah es cilinder $4000 \mathrm{~kg}+$ es serut $3000 \mathrm{~kg}=7000 \mathrm{~kg}$, dari 7000:4000*Total /bulan.

2. Es serut $3000 \mathrm{~kg}$ Perhitungan Harga Pokok Produksi Biaya Bahan, Biaya Tenaga Kerja dan Biaya Overhead Pabrik yaitu dari jumlah es cilinder $4000 \mathrm{~kg}+$ es serut $3000 \mathrm{~kg}=7000 \mathrm{~kg}$, dari 7000:3000*Total /bulan. 


\subsubsection{Perbandingan Perhitungan Harga Pokok Produksi Es Cilinder Dan Es Serut Dengan}

Menggunakan Perhitungan Perusahaan dan Metode Harga Pokok Proses

Tabel 4.36

Laporan Harga Pokok Produksi Es Abadi Sorong

Bulan Januari - Des ember 2015

\begin{tabular}{|c|c|c|c|c|c|}
\hline Bulan & B & \begin{tabular}{|c|} 
Biaya \\
Tenaga Ke rja \\
\end{tabular} & BOP & & h \\
\hline Januari & 13.000 .000 & $\operatorname{Rp} 22.165 .000$ & Rp 35.356.372 & $\mathrm{Rp}$ & 70.521 .372 \\
\hline Februari & Rp 12.000.000 & Rp 22.165.000 & Rp 33.935.700 & $\mathrm{Rp}$ & 68.1 \\
\hline Maret & $\operatorname{Rp} 13.5$ & Rp 22.165.000 & Rp 34.902.483 & $\mathrm{Rp}$ & 483 \\
\hline April & Rp 13.000.000 & Rp 22.165.000 & Rp 35.2. & $\mathrm{Rp}$ & $70 .{ }^{3}$ \\
\hline Mei & Rp 13.500.000 & Rp 22.165.000 & $\operatorname{Rp} 36.6$ & $\mathrm{Rp}$ & 72.320 .799 \\
\hline Juni & Rp 13.000.000 & Rp 22.165.000 & $\operatorname{Rp} 40.7$ & $\mathrm{Rp}$ & 75. \\
\hline Juli & Rp 12. & Rp 22.1 & Rp 34 & $\mathrm{Rp}$ & .000 \\
\hline Agus & Rp 13. & Rp 22.1 & Rp 31. & $\mathrm{Rp}$ & 66. \\
\hline September & Rp 13.000.000 & Rp 22.1 & Rp 22. & $\mathrm{Rp}$ & 57. \\
\hline Okto & Rp 13 & Rp 22.1 & $\mathrm{Rp} 35$. & $\mathrm{Rp}$ & 71.1 \\
\hline Nove & Rp 13.0 & Rp 22.1 & Rp 36. & $\mathrm{Rp}$ & 71.237.808 \\
\hline Desembe & p 13.000 .000 & Rp 22.165.000 & $\mathrm{Rp} 36.871 .900$ & $\mathrm{Rp}$ & 72.036 .900 \\
\hline \multicolumn{4}{|c|}{ Total } & \multicolumn{2}{|c|}{ Rp 835.876.873 } \\
\hline
\end{tabular}

Sumber Data : Es Abadi Sorong

Tabel 4.37

Laporan Harga Pokok Produksi

Bulan Januari - Desember 2015

\begin{tabular}{|l|ll|ll|ll|lr|}
\hline \multicolumn{1}{|c|}{ Bulan } & \multicolumn{2}{|c|}{ Bahan } & $\begin{array}{c}\text { B iaya } \\
\text { Tenaga Ke rja }\end{array}$ & & \multicolumn{2}{c|}{ BOP } & \multicolumn{2}{c|}{ Jumlah } \\
\hline Januari & $\mathrm{Rp}$ & 13.000 .000 & $\mathrm{Rp}$ & 8.060 .000 & $\mathrm{Rp}$ & 66.628 .872 & $\mathrm{Rp}$ & 87.688 .872 \\
Februari & $\mathrm{Rp}$ & 12.000 .000 & $\mathrm{Rp}$ & 8.060 .000 & $\mathrm{Rp}$ & 64.435 .700 & $\mathrm{Rp}$ & 84.495 .700 \\
Maret & $\mathrm{Rp}$ & 13.500 .000 & $\mathrm{Rp}$ & 8.060 .000 & $\mathrm{Rp}$ & 65.402 .483 & $\mathrm{Rp}$ & 86.962 .483 \\
April & $\mathrm{Rp}$ & 13.000 .000 & $\mathrm{Rp}$ & 8.060 .000 & $\mathrm{Rp}$ & 66.462 .917 & $\mathrm{Rp}$ & 87.522 .917 \\
Mei & $\mathrm{Rp}$ & 13.500 .000 & $\mathrm{Rp}$ & 8.060 .000 & $\mathrm{Rp}$ & 67.155 .799 & $\mathrm{Rp}$ & 88.715 .799 \\
Juni & $\mathrm{Rp}$ & 13.000 .000 & $\mathrm{Rp}$ & 8.060 .000 & $\mathrm{Rp}$ & 71.255 .412 & $\mathrm{Rp}$ & 92.315 .412 \\
Juli & $\mathrm{Rp}$ & 12.500 .000 & $\mathrm{Rp}$ & 8.060 .000 & $\mathrm{Rp}$ & 66.072 .500 & $\mathrm{Rp}$ & 86.632 .500 \\
Agustus & $\mathrm{Rp}$ & 13.500 .000 & $\mathrm{Rp}$ & 8.060 .000 & $\mathrm{Rp}$ & 61.593 .720 & $\mathrm{Rp}$ & 83.153 .720 \\
September & $\mathrm{Rp}$ & 13.000 .000 & $\mathrm{Rp}$ & 8.060 .000 & $\mathrm{Rp}$ & 52.759 .382 & $\mathrm{Rp}$ & 73.819 .382 \\
Oktober & $\mathrm{Rp}$ & 13.500 .000 & $\mathrm{Rp}$ & 8.060 .000 & $\mathrm{Rp}$ & 34.850 .000 & $\mathrm{Rp}$ & 56.410 .000 \\
November & $\mathrm{Rp}$ & 13.000 .000 & $\mathrm{Rp}$ & 8.060 .000 & $\mathrm{Rp}$ & 66.572 .808 & $\mathrm{Rp}$ & 87.632 .808 \\
Desember & $\mathrm{Rp}$ & 13.000 .000 & $\mathrm{Rp}$ & 8.060 .000 & $\mathrm{Rp}$ & 67.371 .900 & $\mathrm{Rp}$ & 88.431 .900 \\
\hline \multicolumn{10}{|c|}{ Total } & $\mathrm{Rp}$ & 1.003 .781 .493 \\
\hline
\end{tabular}

Sumber : Data diolah 
Tabel 4.38

Perbandingan Perhitungan Harga Pok ok Produksi Es Cilinder \&

Ees Serut Dengan Es Abadi Sorong

Bulan Januari - Desember 2015

\begin{tabular}{|l|lr|lr|ll|}
\hline \multicolumn{1}{|c|}{ Bulan } & \multicolumn{2}{|c|}{ Es Abadi } & \multicolumn{2}{c|}{$\begin{array}{c}\text { Metode Harga } \\
\text { Pokok Proses }\end{array}$} & \multicolumn{2}{c|}{ Selisih } \\
\hline Januari & $\mathrm{Rp}$ & 70.521 .372 & $\mathrm{Rp}$ & 87.688 .872 & $\mathrm{Rp}$ & 17.167 .500 \\
Februari & $\mathrm{Rp}$ & 68.100 .700 & $\mathrm{Rp}$ & 84.495 .700 & $\mathrm{Rp}$ & 16.395 .000 \\
Maret & $\mathrm{Rp}$ & 70.567 .483 & $\mathrm{Rp}$ & 86.962 .483 & $\mathrm{Rp}$ & 16.395 .000 \\
April & $\mathrm{Rp}$ & 70.377 .917 & $\mathrm{Rp}$ & 87.522 .917 & $\mathrm{Rp}$ & 17.145 .000 \\
Mei & $\mathrm{Rp}$ & 72.320 .799 & $\mathrm{Rp}$ & 88.715 .799 & $\mathrm{Rp}$ & 16.395 .000 \\
Juni & $\mathrm{Rp}$ & 75.920 .412 & $\mathrm{Rp}$ & 92.315 .412 & $\mathrm{Rp}$ & 16.395 .000 \\
Juli & $\mathrm{Rp}$ & 69.465 .000 & $\mathrm{Rp}$ & 86.632 .500 & $\mathrm{Rp}$ & 17.167 .500 \\
Agustus & $\mathrm{Rp}$ & 66.758 .720 & $\mathrm{Rp}$ & 83.153 .720 & $\mathrm{Rp}$ & 16.395 .000 \\
September & $\mathrm{Rp}$ & 57.424 .382 & $\mathrm{Rp}$ & 73.819 .382 & $\mathrm{Rp}$ & 16.395 .000 \\
Oktober & $\mathrm{Rp}$ & 71.145 .380 & $\mathrm{Rp}$ & 56.410 .000 & $\mathrm{Rp}$ & 14.735 .380 \\
November & $\mathrm{Rp}$ & 71.237 .808 & $\mathrm{Rp}$ & 87.632 .808 & $\mathrm{Rp}$ & 16.395 .000 \\
Desember & $\mathrm{Rp}$ & 72.036 .900 & $\mathrm{Rp}$ & 88.431 .900 & $\mathrm{Rp}$ & 16.395 .000 \\
\hline
\end{tabular}

Sumber: Data diolah

Dari tabel di atas dapat diketahui bahwa perhitungan menurut es abadi sorong dengan metode harga pokok proses menurut penulis memiliki perbedaan. Pada perhitungan harga pokok produksi dengan menggunakan metode harga pokok proses yang dihasilkan lebih besar dibandingkan dengan perhitungan usaha yang digunakan. Hal ini karena menggunakan metode harga pokok proses karena semua biaya dirinci secara jelas, baik biaya bahan, biaya tenaga kerja dan biaya overhead pabrik seperti biaya listrik, biaya plastik, biaya pemeliharaan peralatan dan kendaraan serta biaya penyusutan mesin produksi dan biaya penyusutan gedung pabrik sedangkan pada es abadi perhitungan yang dihasilkan lebih kecil karena pemilik tidak memasukkan biaya overhead pabrik secara rinci ke dalam biaya produksinya.

\section{PENUTUP}

\subsection{Kesimpulan}

Berdasarkan hasil penelitian dan pembahasan yang dilakukan oleh penulis dapat ditarik kesimpulan sebagai berikut :

1. Perhitungan harga pokok produksi yang dilakukan oleh Pabrik Es Batu "Es Abadi" masih sangat sederhana dengan menghitung biaya-biaya yang dikeluarkan dalam proses produksi, biaya yang dihitung oleh Pabrik Es Batu "Es Abadi" sebagai biaya produksi adalah air, biaya tenaga kerja, gaji bagian produksi, gaji bagian penjualan, biaya bahan bakar solar dan biaya listrik. Masih terdapat biaya overhead yang dikeluarkan dalam proses produksi namun pabrik es batu "Es Abadi" tidak menghitung biaya tersebut. Hasil perhitungan harga pokok produksi yang dilakukan Pabrik Es Batu "Es Abadi" sebesar Rp 835.876.873

2. Sedangkan perhitungan biaya produksi yang dilakukan dengan metode harga pokok proses pada Pabrik Es Batu "Es Abadi" ialah dengan menghitung seluruh biaya yang dikeluarkan dalam proses produksi es. Adapun biaya yang dibebankan pada biaya air (bahan baku), biaya bahan bakar solar, biaya listrik, ganti oli mesin produksi, biaya plastik, biaya perawatan dan pemeliharaan mesin, serta biaya penyusutan peralatan, mesin, dan gedung pabrik. Hasil perhitungan biaya produksi dengan metode harga pokok proses adalah $\mathrm{Rp}$ 1.003.781.493

3. Perhitungan harga pokok produksi dengan metode perusahaan dan metode 
harga pokok proses memiliki perbedaan. Pada perhitungan harga pokok produksi dengan metode harga pokok proses harga pokok produksi yang dihasilkan lebih besar dibandingkan dengan perhitungan harga pokok produksi dengan metode perusahaan. Selisih biaya produksi antara kedua metode tersebut adalah harga pokok produksi yang terlihat pada tabel 4.38 .

\subsection{Saran}

Berdasarkan hasil penelitian ada beberapa saran antara lain:

1. Pabrik Es Batu "Es Abadi Sorong" sebaiknya menghitung biaya pemeliharaan mesin dan kendaraan, dan biaya penyusutan peralatan dan mesin. Karena hal ini merupakan elemen yang penting untuk menghitung biaya overhead pabrik.

2. Sebaiknya Pabrik Es Batu "Es Abadi" dalam menghitung biaya produksinya menggunakan metode harga pokok proses karena metode ini lebih akurat dibandingkan dengan metode yang dilakukakan oleh perusahaan. Metode harga pokok proses merinci seluruh biaya produksi yang terkait dengan proses produksi sehingga hasil perhitungan yang diperoleh menunjukkan hasil akurat yang dikeluarkan selama proses produksi.

3. Penelitian ini diharapkan dapat memberikan tambahan wawasan atau pemahaman kepada perusahaan manufaktur mengenai perhitungan harga pokok produksi dengan menggunakan metode harga pokok proses.

\section{DAFTAR PUSTAKA}

Al Haryono Jusup, M.B.A.,AK, Drs; Dasardasar akuntansi, jilid 2; Penerbit Sekolah Tinggi Ilmu Ekonomi YPKN, Yogyakarta; 2011.

Bastian Bustami dan Nurlela; Akuntansi Biaya, Edisi 1; Penerbit Mitra Wacana Media, Jakarta; 2009.
Don R. Hansen dan Maryanne M. Mowen akuntansi manajemen Edisi 4; penerbit Yogyakarta 2000.

Mulyadi, M.Sc, Drs; Akuntansi biaya, Edisi 5; Penerbit Yogyakarta; 2010.

Wiliam K. Carter \& usry, Milton F; Biaya Edisi 13; Penerbit Salemba Empat, Jakarta 2006.

Supriyono; Akuntansi Biaya, Edisi 2: Penerbit BPFE YOGYAKARTA, 2012. 